\section{Controller of Guided Weapons and Electronics: Dr. R. Cockburn, C.B., O.B.E.}

DR. R. CockBurn, whose appointment as controller of guided weapons and electronics was announced in October, is the first scientist to hold a post of controller in the Ministry of Supply. He entered the Scientific Civil Service in 1937 at the Royal Aircraft Establishment, Farnborough, as a member of the team engaged on the development of very highfrequency communications for the Royal Air Force. During 1939-45 he was at the Telecommunications Research Establishment as hoad of the Radio Countermeasures Division. This division was responsible for countering the German navigation systems over Great Britain and for the interception and analysis of their radar systems. Later the division developed for Bomber Command airborne and ground equip. ment to counter the German air defences. This work culminated in an elaborate system of diversion decoying and jamming in support of the invasion of Europe. During 1945-48 Dr. Cockburn was in the Nuclear Physics Division at the Atomic Energy Research Establishment at Harwell and for a short time at Chalk River. In 1948 he became scientific adviser to the Air Ministry and held this post until 1954, when he returned to the Ministry of Supply as principal director of seientific research (guided weapons and electronics). $\mathrm{He}_{\mathrm{e}}$ became deputy controller of electronics in 1955. Before entering Government service, Dr. Cockburn taught physics at West Ham Municipal College and was engaged in research on transit time effects in valves. He published papers in the Proceedings of the Physical Society. As a result of this work he was awarded the Ph.D. degree of the University of London in 1939. $\mathrm{He}$ was appointed O.B.E. in 1946 and C.B. in 1953. In 1947 he was awarded the American Congressional Medal for Merit for his work in the field of radio warfare.

\section{Ageing and Industry}

A statistral inquiry into the age-composition of workers in the British iron and steel industry has been carried out by C. Fleming, of the Department of Social and Industrial Medicine at the University of Sheffield. Not unexpectedly, the investigation shows that the work-population has 'aged' over the past two decades and that there is considerable variations between the age structure of various com. panies and between firms in different centres of the country. Investigation has also been made into the age structure of different sections of the iron and steel industry and, surprisingly, shows that blast furnaces have the greatest percentage of older men in the industry, while foundries, which have had recruitment difficulties, have almost the lowest. Apart from a plea for the establishment of a science of gerontology, the author makes few suggestions of any practical value to those in the industry, who must have been impressed by the extensive nature of this statistical inquiry. Montion might have been made of the adjustments necessary within the industry to meet trade union insistence on promotion by seniority and of the difficulties which the iron and steel industry, in common with others, will have to overcome in providing adequate training schemes for those 'extra' youths of the war-time birth-rate 'bulge' who will shortly begin to leave school. Their employment will cause considerable change in the industry's age structure over the next ten years.

\section{Philosophical Outlook of Mansel}

IN "The Religious Philosophy of Dean Mansel" (Friends of Dr. Williams's Library, Tenth Lecture, 1956. Pp. 24. London: Oxford University Press, 1956. 3s. 6d. net), Dr. W. R. Matthews, Dean of St. Paul's, discusses the philosophical outlook of one of the most interesting (and perhaps among the least appreciated) of his predecessors. Mansel's Bampton Lectures of 1858 opened up a deep argument with F. D. Maurice, which touched the roots of episternology. Briefly, it is held that there is an almost complete barrier between theology and philosophy (the latter, for Mansel, is no sort of serving-maid to the former), whereas Maurice, in his dislike of all systems, appears more liberal in maintaining the wholeness of know. ledge. The essentially static nature of theology as propounded by Mansel is characteristic: for him it is not a science at all, and quite incapable of producing any progressive cognition of the Divine. Dr. Matthews is certain that he would have rejected any alleviation of his metaphysical impasse, having no more use for the analogia entis than Karl Barth has now for it in his 'crisis theology'. Yet Mansel's type of agnosticism stops well short of Otto's 'wholly other', and asserts man's mental limitations as the decisive factor. In all, a clear and concise summary of a significant movement, not without consequence for contemporary thought.

\section{Scientific Research in British Universities}

A FuRTher edition of "Scientific Research in British Universities", compiled by the Department of Scientific and Industrial Research (pp. vii +372 . London: H.M. Stationery Office, 1956. 21s. net) from material collected by the British Council from heads of university departments, gives notes on scientific research in progress in British universities and university colleges during the session 1955-56 in sufficient detail to indicate the scope of activity of the department and of each research team. Only those researches are included which were actively pursued during the session, or on which information has been published by the staff of the department within the past four yoars, or in which the head of the department normally accepts research students. The entries are arranged alphabetically by universities, and there are also name- and subject-indexes.

\section{Commonwealth University Interchange}

THe Committee for Commonwealth University Interchange set up in 1948 to facilitate the move. ment within the Commonwealth of university teachers and graduates has published a report on its eight years work. A total of 389 visits has so far been arranged and 89 universities and university colleges from the United Kingdom, Canada, Australia, New Zealand, South Africa, India, Pakistan, Malta, Ceylon, Hong Kong, Malaya, Singapore, Gold Coast, Nigeria, East Africa and the West Indies have participated, the participants ranging from vice-chancellors and scholars of international repute to young postgraduate workers at the outset of their academic career. The demand for the awards expanded throughout the period covered by the report and requests for awards for the academic year 1956-57 represented a maximum. Lists of awards in each of the three categories are appended, together with an analysis of the distribution by universities and by centres. The scheme appears to have fulfilled at least in part the aims of its promoters, but the $£ 12,583$ available for $1955-56$ was sufficient to meet 